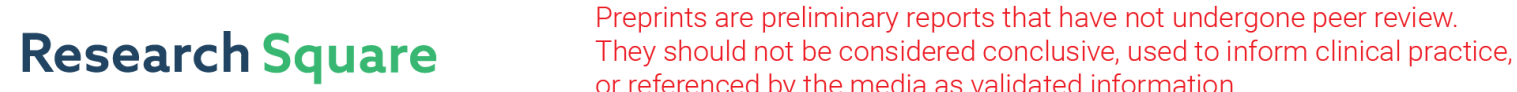 or referenced by the media as validated information. \\ Current Account Deficits and Sustainability in Africa: Evidence from Cointegration Approach
}

\section{Eugene Kouassi}

Universite Felix Houphouet-Boigny

\section{Soro Kolotioloman}

Universite Peleforo Gon Coulibaly

James Sharka Juana ( $D$ juanajames64@gmail.com )

Botswana International University of Science and Technology (BIUST) https://orcid.org/0000-0003-

1119-9257

\section{Research}

Keywords: Current account, Regional blocs, Exchange rate regime, Income level, Africa, Cointegration.

Posted Date: August 14th, 2020

DOI: https://doi.org/10.21203/rs.3.rs-38275/v1

License: (c) (i) This work is licensed under a Creative Commons Attribution 4.0 International License. Read Full License 


\title{
CURRENT ACCOUNT DEFICITS AND SUSTAINABILITY IN AFRICA: EVIDENCE FROM COINTEGRATION APPROACH
}

\author{
Eugene Kouassi \\ Department of Economics, University of Felix Houphouet Boigny, Abidjan, Cote d'Ivoire \\ Email: Eugene.kouassi@gmail.com \\ Soro Kolotidoman \\ Department of Economics, University of Peleforo Gon Coulibaly, Korhago, Cote d'Ivoire \\ Email: sorokolom@gmail.com \\ James Sharka Juana \\ Department of Business Management \& Entrepreneurship \\ Botswana International University of Science of Science \& Technology (BIUST) \\ P/Bag 16, Palapye, Botswana \\ Email: juanaj@biust.ac.bw; juanajames64@gmail.com \\ Tel: +2674931166
}

\section{Current Account Deficits and Sustainability in Africa: Evidence from Cointegration}

\section{Approach}

\begin{abstract}
:
This paper gives an overview of current accounts sustainability in forty African countries over the 1980-2016 period. The paper goes through by testing if this sustainability depends on regional blocs, income levels or exchange rate regimes. For this purpose, the paper employs a formal theoretical framework, recent cointegration techniques like threshold cointegration to test for long-run relationship between variables. Results reveal that although exports and imports plus interest payments on external debt are cointegrated in African
\end{abstract}


economies, the current accounts are weakly sustainable in $45 \%$ of African economies and unsustainable in only $8 \%$. Among regional blocs, income level and exchange rate regime groupings, only exchange rate regime groupings have a significant effect on current account sustainability. Since current account is strong sustainable in countries operating flexible and intermediate exchange rate regimes than countries operating fixed regimes.

Keywords: Current account, Regional blocs, Exchange rate regime, Income level, Africa, Cointegration.

JEL Codes: F32, C23, C22

June, 2020

\section{Introduction}

The aim of this paper is to analyze the sustainability of current accounts in African countries over the period 1980 to 2016, paying a specific attention to regional blocs, income levels and exchange rate regimes ${ }^{1}$ (see Aizenman and Sun, 2010; Amba et al., 2017; Apergis et al., 2000; Baharumshah et al., 2005; Chang et al., 2012; Chen, 2011; Gnimassoun and Coulibaly, 2014; Hashiguchi and Hamori, 2012). African economies are generally concerned by a lack of credibility, which makes external financing more difficult and costly (i.e. subject to a high-risk premium). Given the growing role of international trade in Africa, many economies on the

\footnotetext{
1 There is a relevant discussion on the role of exchange rate regimes in the adjustment of current accounts and therefore in current account sustainability. Likewise, Mundell (1961) theory argues that the exchange rate regime affects the capacity of an economy to deal with shocks and thus to absorb (external) imbalances. See e.g. Gnimassoun (2014) for a large exposition about the role of exchange rate regimes in current account sustainability.
} 
continent are confronted with important and rising trade and current account deficits. It is feared that rising current account deficits will augment Africa's future debt burden and make the continent vulnerable to financial crises. Most of these are low-income countries suffering from over-indebtedness or high risk of debt distress. For instance, according to IMF (2017), the number of (Sub-Saharan) African countries facing high risk of debt distress has increased from seven in 2013 to twelve in 2016 ( World Bank, 2018). Factors accounting for this situation include a widening in fiscal deficits, slow growth, the slump in commodity prices, and exchange rate depreciations in the affected countries. Against this backdrop, the paper adopts a formal theoretical framework as well as recent cointegration techniques to analyze current account sustainability in 40 African countries (see Chang et al., 2012; Chen, 2011; Gnimassoun and Coulibaly, 2014; and Hashiguchi and Hamori, 2012).

This paper differs from previous studies from at least four point of views: (i) since sustainability is a very sensitive question, it is analyzed both at panel as well as time series levels; (ii) to avoid misleading results heterogeneity and spatial analysis are accounted for; (iii) recent advances in econometric analysis are used in order to ascertain some influential results; (iv) finally large panels are used to avoid shortcomings of short dimension panel data. (see Baltagi, 2013).

The remainder of the paper proceeds as follows. Section 2 provides a synopsis of the available literature on the current account sustainability especially in developing countries. Section 3 briefly discusses on the theoretical framework of the current account sustainability and introduces econometric methodologies. Section 4 describes the data and makes some preliminary analysis. Section 5 presents the empirical findings. Section 6 concludes the paper.

\section{Related Literature Review}


A lot of literature has been devoted to current account sustainability, resulting in mixed conclusions depending on the countries, the sample, and the methodological approach. For instance, a number of studies have examined the sustainability of current account at the individual country level (see Husted, 1992; Apergis et al., 2000; Clarida, 2006; Aizenman and Sun, 2010; Christopoulos and León-Ledesma, 2010; Karunaratne, 2010; Ventosa-Santaulauria et al., 2013; Ndoricimpa et al., 2014; Rinaldi et al., 2014; Tiwari, 2015). Other authors have done similar studies for a group of countries (see Roubini and Wachtel, 1999; Baharumshah et al., 2005; Kim et al., 2009; Chen, 2011; Chang et al., 2012; Donoso and Martin, 2014; Gnimassoun and Coulibaly, 2014; Lanzafame, 2014; Sahoo et al., 2016; Amba et al., 2017). Narayan and Narayan (2005) investigated whether a long-run relationship exists between exports and imports for 22 least developed countries. This is an important issue; because evidence of cointegration ensures that trade imbalances are sustainable. The results indicate that exports and imports are cointegrated only for six out of the 22 countries, and the coefficient on exports is less than unity. Hashiguchi and Hamori (2012) studied the sustainability of trade balances in the sub-Saharan African regions, using both the panel unit root test and the crosssectional augmented version of the IPS (see Im, Pesaran and Shin, 2003) test. The empirical results based on the IPS test indicate that the balance of trade in the sub-Saharan African regions is sustainable; but the CIPS test reveals that it is not sustainable. Similarly, Ndoricimpa et al. (2014) examined the long-run relationship between imports and exports in East African Community using threshold cointegration techniques. The finding suggest that current accounts are weakly sustainable only for three countries. Gnimassoun and Coulibaly (2014) examined the sustainability of current accounts in Sub-Saharan Africa and determined whether this sustainability depends on only the exchange rate regimes. Their findings show that current accounts have been sustainable in Sub-Saharan Africa countries over the 1980-2011 period. 
However, this sustainability has been lower for countries operating a fixed exchange rate regime or belonging to a monetary union.

\section{Econometric Methodology}

\subsection{Theoretical Framework on Current Account}

In this paper, we use the trade flows-based approach which relies on the theoretical framework presented below and which is more relevant for ECOWAS countries ${ }^{2}$. Testing for the cointegration relationship between imports and exports as a way of checking the sustainability of current account deficits was first proposed by Hakkio and Rush (1991) and Husted (1992). They proposed a conceptual framework in which a representative individual of a small open economy faces the following budget constraint,

$$
C_{0}=Y_{0}+B_{0}-I_{0}-\left(1+r_{0}\right) B_{t-1}
$$

where $C_{0}, Y_{0}$ and $I_{0}$ stand for current consumption, income and Investment respectively, and $B_{0}$ is the current borrowing, $\left(1+r_{0}\right) B_{t-1}$ is the initial debt size and $r_{0}$ is the world interest rate. Since equation 1 must hold for every time period, these period by period budget constraints can be combined to form the economy's intertemporal budget constraint. Iterating equation (1) forward we get (2),

$$
B=\sum_{t=1}^{\infty} w_{t}\left(X_{t}-M M_{t}\right)+\lim _{n \rightarrow \infty} w_{n} B_{n}
$$

\footnotetext{
2 In practice, there are three (03) empirical approaches for testing current account sustainability. The first one is the external intertemporal budget constraint approach based on trade flows (see Milesi-Ferrett and Razin, 1996; Faruqee and Debelle, 1998; Kincaid et al., 2001; Chinn and Prasad, 2003; Jeong and Mazier, 2003; Coudert and Couharde, 2007; Lee et al., 2008; Lane and Milesi-Ferretti, 2012, and Gnimassoun et al. (2013), among others). The second is the valuation effect approach based on the dynamic of net foreign assets. And the third definition is the saving-investment approach based on disequilibria between saving and investment (One can revisit literature by Edwards (2005) and Lane and Milesi-Ferretti (2012), among others.).
} 
where exports $X_{t}$ minus imports $M M_{t}$ represent trade balance in period $t, w_{t}$ is the discount factor defined as the product of the first $t$ value of $\lambda_{t}=1 /\left(1+r_{t}\right)$. To get a testable empirical model, Husted (1992) rewrites (1). Assuming that the world interest rate is stationary with unconditional mean $r$, equation (1) can be expressed by,

$$
X_{t}+B_{t}=W_{t}+(1+r) B_{t-1}
$$

where $W_{t}=M M_{t}+\left(r_{t}-r\right) B_{t-1}$. Equation (3) can be solved forward to obtain,

$$
M M_{t}+r_{t} B_{t-1}=X_{t}+\sum_{j=0}^{\infty} \lambda^{j-1}\left[\Lambda X_{t+j}-\Delta W_{t+j}\right]+\lim _{j \rightarrow \infty} \lambda^{t+j} B_{t+j}
$$

where $\lambda=1 /(1+r)$ and $\Delta$ is the first difference operator. Husted (1992) assumes further that $W_{t}$ and $X_{t}$ are non-stationary processes integrated of order one which can be written as,

$$
\left\{\begin{array}{l}
W_{t}=\theta_{1}+W_{t-1}+\varrho_{1 t} \\
X_{t}=\theta_{2}+X_{t-1}+\varrho_{2 t}
\end{array}\right.
$$

where $\theta_{j}$ are drift parameters and $\varrho_{j t}$ are stationary processes. Substituting equations (5) in equation (4) and rearranging gives,

$$
X_{t}=\frac{(1+r)^{2}}{r}\left(\theta_{1}-\theta_{2}\right)+\left(M M_{t}+r_{t} B_{t-1}\right)-\lim _{j \rightarrow \infty} \lambda^{t+j} B_{t+j}+\sum_{j=0}^{\infty} \lambda^{j-1}\left(\varrho_{1 t}-\varrho_{2 t}\right)
$$

By letting $\beta=\left[(1+r)^{2} / r\right]\left(\theta_{1}-\theta_{2}\right)$ and $\varrho_{t}=\sum_{j=0}^{\infty} \lambda^{j-1}\left(\varrho_{1 t}-\varrho_{2 t}\right)$, equation $(6)$ can be written as,

$$
X_{t}=\beta+\left(M M_{t}+r_{t} B_{t-1}\right)-\lim _{j \rightarrow \infty} \lambda^{t+j} B_{t+j}
$$

Finally, equation (7) can be written as follows where $M_{t}=M M_{t}+r_{t} B_{t-1}$ and assuming that $\lim _{j \rightarrow \infty} \lambda^{t+j} B_{t+j}=0$, 


$$
X_{t}=\beta+\delta M_{t}+\varrho_{t}
$$

According to Hakkio and Rush (1991) and Husted (1992), the current account deficits are sustainable if exports $X_{t}$ and imports plus interest payments on external debt $M_{t}$ are cointegrated. It has been argued however that for the current account deficits to be strongly sustainable, the sufficient condition should be that $\delta=1$ and in case $0<\delta<1$, they are only weakly sustainable (see for example, Herzer et al. 2005; Ongan, 2008; Rahman, 2011; and Tiwari, 2015).

\subsection{Westerlund ECM cointegration tests}

Westerlund (2007) developed four new panel cointegration tests that are based on structural rather than residual dynamics and, therefore, do not impose any common-factor restriction. The idea is to test the null hypothesis of no cointegration by inferring whether the error-correction term in a conditional panel error-correction model is equal to zero. The tests are all normally distributed and are enough to accommodate unit-specific short-run dynamics, unit-specific trend, slope parameters, and cross-sectional dependence. Two tests are designed to test the alternative hypothesis that the panel is cointegrated as a whole, while the other two test the alternative that at least one unit is cointegrated,

$\Delta y_{i t}=\delta_{i}^{\prime} d_{t}+\alpha_{i}\left(y_{i, t-1}-\beta_{i}^{\prime} x_{i, t-1}\right)+\sum_{j=1}^{p_{i}} \alpha_{i j} \Delta y_{i, t-j}+\sum_{j=-q_{i}}^{p_{i}} \gamma_{i j} \Delta x_{i, t-j}+e_{i t}$

$\alpha_{i}$ provides an estimate of the speed of error-correction towards the long-run equilibrium

$y_{i t}=-\left(\beta^{\prime}{ }_{i} / \alpha_{i}\right) x_{i t}$ for that series $i$. Westerlund (2007) computes the following four statistics

$$
\begin{aligned}
G_{\tau} & =\frac{1}{N} \sum_{i=1}^{N} \frac{\widehat{\alpha}_{i}}{\operatorname{se}\left(\widehat{\alpha}_{i}\right)} ; G_{\alpha}=\frac{1}{N} \sum_{i=1}^{N} \frac{T \widehat{\alpha}_{i}}{\widehat{\alpha}_{i}(1)} \\
P_{\tau} & =\frac{\widehat{\alpha}}{\operatorname{se}(\widehat{\alpha})} ; P_{\alpha}=T \widehat{\alpha}
\end{aligned}
$$


where $\widehat{\alpha}$ is the estimate common error correction parameter and $s e(\cdot)$, the associate standard error of an input random variable. The $G_{\alpha}$ and $G_{\tau}$ test statistics test $H_{0}: \alpha_{i}=0$ for all $i$ versus $H_{1}: \alpha_{i}<0$ for at least one $i$. These statistics start from a weighted average of the individually estimated $\alpha_{i}$ 's and their $t$-ratio's, respectively. The $P_{\alpha}$ and $P_{\tau}$ test statistics pool information over all the cross-sectional units to test $H_{0}: \alpha_{i}=0$ for all $i$ versus $H_{1}: \alpha_{i}<0$ for all $i$. Rejection of $H_{0}$ should therefore be taken as rejection of cointegration for the panel as a whole. The tests are very flexible and allow for an almost completely heterogeneous specification of both the long and short-run parts of the error-correction model, where the latter can be determined from the data. The series are allowed to be of unequal length (see Westerlund, 2007).

\subsection{Bayer-Hanck cointegration approach}

The - linear - cointegration relationship between exports and imports plus IPED is investigated by applying the combined cointegration test developed by Bayer and Hanck (2013). This test provides uniform and reliable cointegration results by integrating the findings of four cointegration approaches, namely Boswijk (1994), Engle and Granger (1987), Johansen (1988) and Banerjee et al. (1998) which are expressed by BO, EG, JOH, and BDM respectively. This test gives efficient estimates by ignoring the nature of multiple testing procedures which gives robust and better results as compared to the individual $t$-test or the system based test. To carry out the combined Bayer-Hank cointegration test, the Fisher's formula is as follows,

$$
E G-J O H=-2\left(\ln \left(P_{E G}\right)+\ln \left(P_{J O H}\right)\right)
$$

$$
E G-J O H-B O-B D M=-2\left(\ln \left(P_{E G}\right)+\ln \left(P_{J O H}\right)+\ln \left(P_{B O}\right)+\ln \left(P_{B D M}\right)\right)
$$


The notations such as $P_{E G}, P_{J O H}, P_{B O}$ and $P_{B D M}$ represent the probability values for the individual cointegration tests such as Engle and Granger (1987), Johansen (1988), Boswijk (1994) and Banerjee et al. (1998), respectively. Fisher's statistics are used to determine whether the cointegration between the variables exists or not. The hypothesis of cointegration is therefore accepted if the computed Fisher's statistics exceed the Bayer and Hanck (2013) critical values.

\subsection{Threshold Cointegration}

Extending Engle and Granger (1987) linear cointegration test, Enders and Granger (1998) and Enders and Siklos (2001) developed a threshold cointegration test where negative and positive deviations from the long-run equilibrium are not corrected in the same way; that is, in which the adjustment toward the long-run equilibrium is asymmetric (see Stigler, 2012). Let $x_{t}$ and $m_{t}$ be the logarithm of exports and imports respectively. Using TAR and M-TAR models, Enders and Siklos (2001) proposes the following steps to test for threshold cointegration. In the first step, the following long-run equilibrium relationship is estimated,

$$
x_{t}=\alpha_{0}+\alpha_{1} m_{t}+\varsigma_{t}
$$

In the next step, the following equation is estimated using Ordinary Least Squares (OLS),

$$
\Delta \widehat{\varsigma}_{t}=I_{t} \rho_{1} \widehat{\varsigma}_{t-1}+\left(1-I_{t}\right) \rho_{2} \widehat{\varsigma}_{t-1}+\sum_{i=1}^{p} \varphi_{i} \Delta \widehat{\varsigma}_{t-i}+\eta_{t}
$$

where $\widehat{\varsigma}_{t}$ is the residuals series from equation (eq:12) and $I_{t}$ is the Heaviside indicator function such that,

$$
I_{t}= \begin{cases}1, & \text { if } \widehat{\theta}_{t} \geq \lambda \\ 0, & \text { if } \widehat{\theta}_{t}<\lambda\end{cases}
$$

where $\lambda$ is the threshold value to be estimated. Equations (13) and (14) with $\widehat{\theta}_{t}=\widehat{\varsigma}_{t}$ together form the threshold autoregressive model (TAR) and equations (13) and (14) with $\widehat{\theta}_{t}=\Delta \widehat{\varsigma}_{t}$ 
form the momentum threshold autoregressive model (M-TAR). The threshold value is selected using Chan (1993) method where the optimum value is such that the residuals sum of squares is at a minimum (see Sun, 2011). From equation (13), to test for threshold cointegration, Enders and Granger (1998) and Enders and Siklos (2001) propose to test the following hypothesis of no threshold cointegration,

$$
H_{0}: \rho_{1}=\rho_{2}=0
$$

The test statistic used is known as $\Phi$ statistic and the critical values are from Enders and Siklos (2001).

\subsection{Estimation Method}

To estimate the cointegrating relationship between exports $\left(x_{i t}\right)$ and imports plus Interest Payment on External Debts (IPED) denoted as, $\left(m_{i t}\right)$ we use the Panel Dynamic Ordinary Least Squares (PDOLS) method developed by Mark and Sul (2003), which is more efficient for estimating a panel cointegration relationship than other competing estimators such as Pooled estimator and Fully Modified Ordinary Least Squares (FMOLS) (see Kao and Chiang, 2001). An advantage of Mark and Sul (2003) method is that it purports that the coefficients are homogeneous between countries in the long-run while they are supposed to be heterogeneous

in the short-run. Consequently, this method partially answers the question of potential heterogeneity between countries of the sample often alleged to several panel data estimators which generally show that the coefficients are homogeneous both in short and long runs. More precisely, the PDOLS procedure consists of augmenting the cointegrating relationship, with leads and lags of the first difference of the explanatory variables which are used as instruments of both explanatory and explained variables,

$$
x_{i t}=\theta_{i}+\varphi_{t}+\gamma_{i} t+\alpha m_{i t}+\varepsilon_{i t}
$$


where in equation (15), $\theta_{i}, \varphi_{t}$ and $\gamma_{i} t$ respectively stand for country specific effects, common time factors and country-specific (or heterogeneous) linear trends that allow for some degree of cross-section independence. This paper considers four different specifications depending on the restriction on deterministic components: a model with only country specific effects $\left(\varphi_{t}=\gamma_{i}=0\right)$, a model with fixed and common time effects $\left(\gamma_{i}=0\right)$, a model with fixed effects and heterogeneous trend $\left(\varphi_{t}=0\right)$ and the complete model of equation (15).

\subsection{Criteria on Strong Sustainability}

An empirical efficiency criterion is used to evaluate and test the strong sustainability in African economies. In panel analysis, current account is expected to be strongly sustainable if after estimating the four (04) specifications of equation (15) at least three (03) estimated specifications do not reject the null hypothesis based on for example the Wald $\chi^{2}$ statistic. In country analysis DOLS model only considers two specifications: (i) only constant and (ii) constant and linear trend. In this case, current account is strongly sustainable if both specifications do not reject the null hypothesis based for instance on the Wald $\chi^{2}$ statistic.

\section{Data and Preliminary Analysis}

\subsection{The Data}

In our study we use annual data on 40 African countries from over a period of 37 years (1980 to 2016). The data are from the World Development Indicators 2018 (see World Bank, 2018). Selected African countries and time span depend only on data availability. We collected data on exports of goods and services $\left(x_{t}\right)$ and imports of goods and services plus interest payments on external debt (IPED), hereafter $\left(m_{t}\right)$. Exports, Imports and IPED are expressed in current US Dollar. We categorised these economies in three (03) groups: regional blocs, income 
level and exchange rate regimes. Regional blocs are Central Africa, Eastern Africa, Northern Africa, Southern Africa and Western Africa. Income level regroups Low income, Middle income and Upper income. Using the World Bank Atlas method of 2018 fiscal year, lowincome economies are defined as those with a Gross National Income (GNI) per capita income of 1,005 US Dollar or less in 2016; middle-income economies are those with a GNI per capita between 1,006 US Dollar and 3,955 US Dollar and upper middle-income economies are those with a GNI per capita between 3,956 US Dollar and 12,235 US Dollar. Exchange rate regime used the de facto classification scheme proposed by Ilzetzki et al. (2008). Relying on this classification, we Categorised African countries into three different exchange rate regimes: fixed, intermediate and flexible ${ }^{3}$ exchange rate regimes.

Figure 1. Export and Import plus interest payments on external debts in Africa

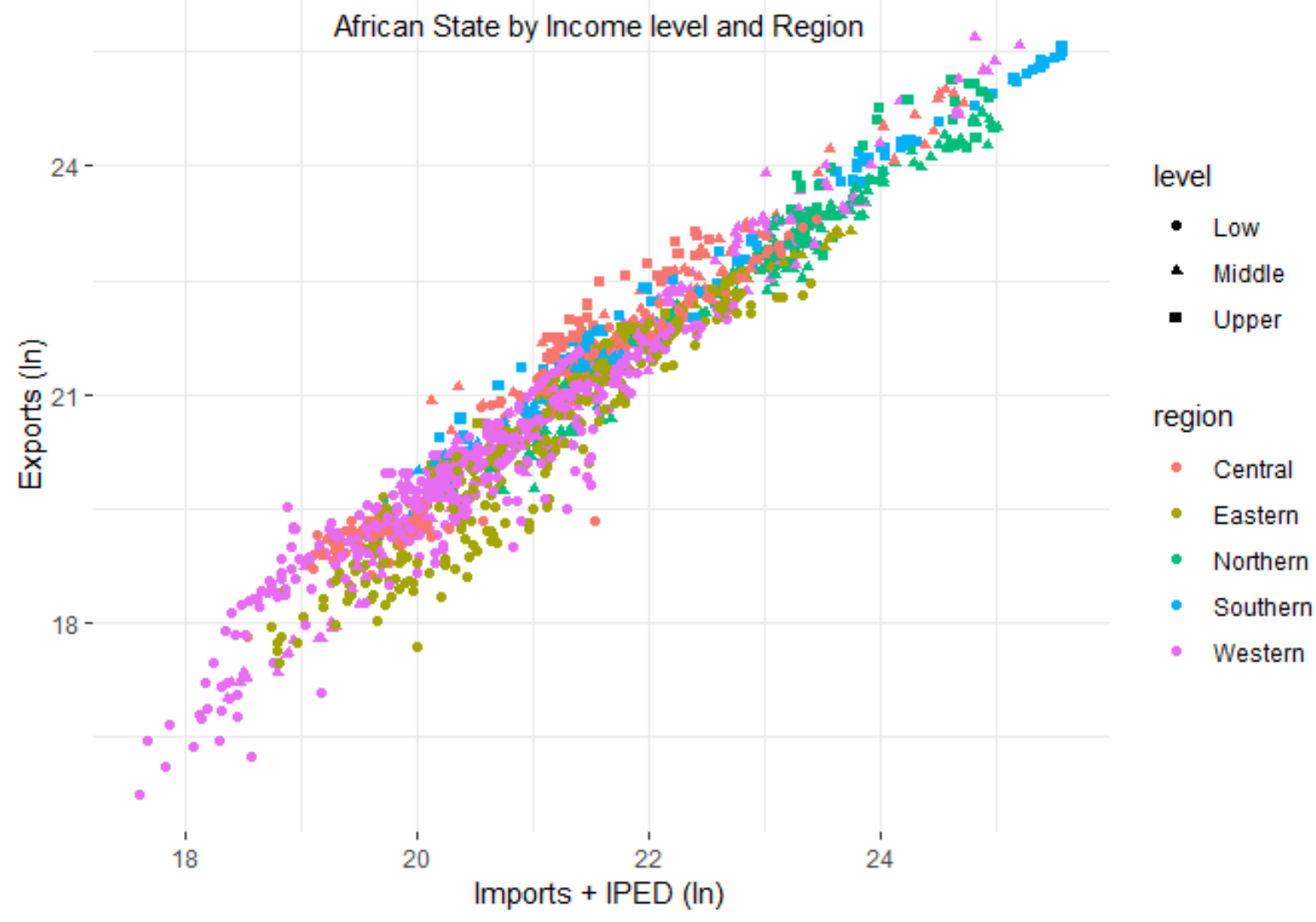

\footnotetext{
${ }^{3}$ We used the same classification as Gnimassoun et al. (2013) and Pancaro and Saborowski (2016).
} 


\subsection{Preliminary Analysis}

Table 1 presents (group) descriptive statistics of exports and imports plus IPED (in logarithm) in Africa. From the Table we find that the mean standard deviation, minimum and maximum of exports and imports are close to each other with imports always greater than exports (except for upper middle-income economies). According to the regional partitioning, Northern Africa exports and imports more goods than the others regional blocs; followed by Southern Africa with an exportation or importation level (in logarithm) around of 22.3. These are followed by Western Africa, with an export-import level around of 20.5. By income level, upper middle-income economies export and import more goods, followed by middle-income economies and finally low-income economies. According to exchange rate regimes, flexible exchange rate economies export and import more goods and services than the others, followed by fixed exchange rate economies and finally intermediate exchange rate economies.

\section{[INSERT TABLE 1 AROUND HERE]}

Figure 1 shows the evolution of exports as a function of imports in African economies. All countries have the same trend and because they are regrouped in the same cloud; there seems to be a long-run relationship between exports and imports plus IPED. Hence, it can be important to investigate the current account deficit of African economies.

\section{Empirical Results}

\subsection{Unit root tests}

Since assuming cross-sectional independence across countries in panel analysis may distort the findings, we undertake empirical analysis that relates imports plus IPED to exports 
and then apply panel estimation techniques with cross-country heterogeneity and dependence. These techniques improve the statistical reliability of our results. In particular, we apply a crosssectional dependence (CD) test using the approach developed by Pesaran (2007). This test employs the correlation coefficients between the time series for each panel country. The null hypothesis of the test is cross-sectional independence. The results of the CD test are reported in Table 2. The results indicate that the null hypothesis of cross-sectional independence is strongly rejected at the $1 \%$ significance level for all exports and imports plus IPED. This suggests the presence of cross-sectional dependence across the panel.

\section{[INSERT TABLE 2 AROUND HERE]}

Table 3 reports the results of panel unit root tests of our variables in level. Focusing on the intercept case, the $\chi^{2}$ test of Maddala and Wu (1999) cannot reject the panel unit root (null hypothesis) among all the variables in level. Whereas, when considering the linear trend, the $\chi^{2}$ test rejects the null hypothesis at lag 0 and 1 for exports.

[INSERT TABLE 3 AROUND HERE]

The last two columns of Table 3 regroup PANICCA tests where the first, the second and the third rows of each variable respectively stands for $P_{a}, P_{b}$ and Pooled Modified SarganBhargava (PMSB) test. As we can see, all these statistics of Reese and Westerlund (2016) cannot reject the panel unit root hypothesis among variables in level. With the above analysis, we conclude that exports and imports are nonstationary variables in level. Having established the 'global' characteristics of exports and imports plus IPED series, we now focus on their 'local' behavior by checking their - country - stationarity properties prior to examining the cointegrating relationship among them. For this purpose, we used Dickey and Fuller (1981) to test the stationarity in the levels and first differences for exports $\left(x_{t}\right)$ and imports plus IPED 
$\left(m_{t}\right)$ in each African economy. The results of the Augmented Dickey-Fuller (ADF) test are presented in Table 4. We consider a specification with drift only and linear trend.

[INSERT TABLE 4 AROUND HERE]

Focusing on exports, results on Table 4 indicate that this variable is integrated of order one or I(1) for each country (except for Egypt and Mozambique). Turning to imports plus IPED, results on Table 4 indicate that this variable is integrated of order one or I(1) for each country (except for Niger and Sierra Leone). For the Egypt, Mozambique, Niger and Sierra Leone, we implement the Zivot and Andrews (2002) unit root test for the variable in first difference. The findings reveal that exports and Imports plus IPED the null hypothesis are stationary in first difference. Results were not reported here but are available on request. Since exports and imports plus IPED are I(1), we can therefore test for the existence of a cointegration relationship between these series in both panel data and time series.

\subsection{Cointegration Results}

To investigate the sustainability of current accounts in Africa according to regional bloc, income level and exchange rate regime, we rely on the cointegration tests proposed by Westerlund (2007) for panel cointegration. We consider two types of models: a model with a constant and a model with both constant and trend. Since we detect cross sectional dependence across countries, we use bootstrap critical value computed on 100 replications. The results are summarized in Table 5. The four test statistics proposed by Westerlund (2007) strongly reject the null hypothesis of no cointegration between exports and imports plus IPED in Africa. This finding remains valid whether we consider regional bloc, income level or exchange rate regime 
4; hence, the Westerlund (2007) test indicates that current accounts in African economies are globally sustainable over the 1980-2016 period.

Figure 2. Non-linear cointegration in African economies by region

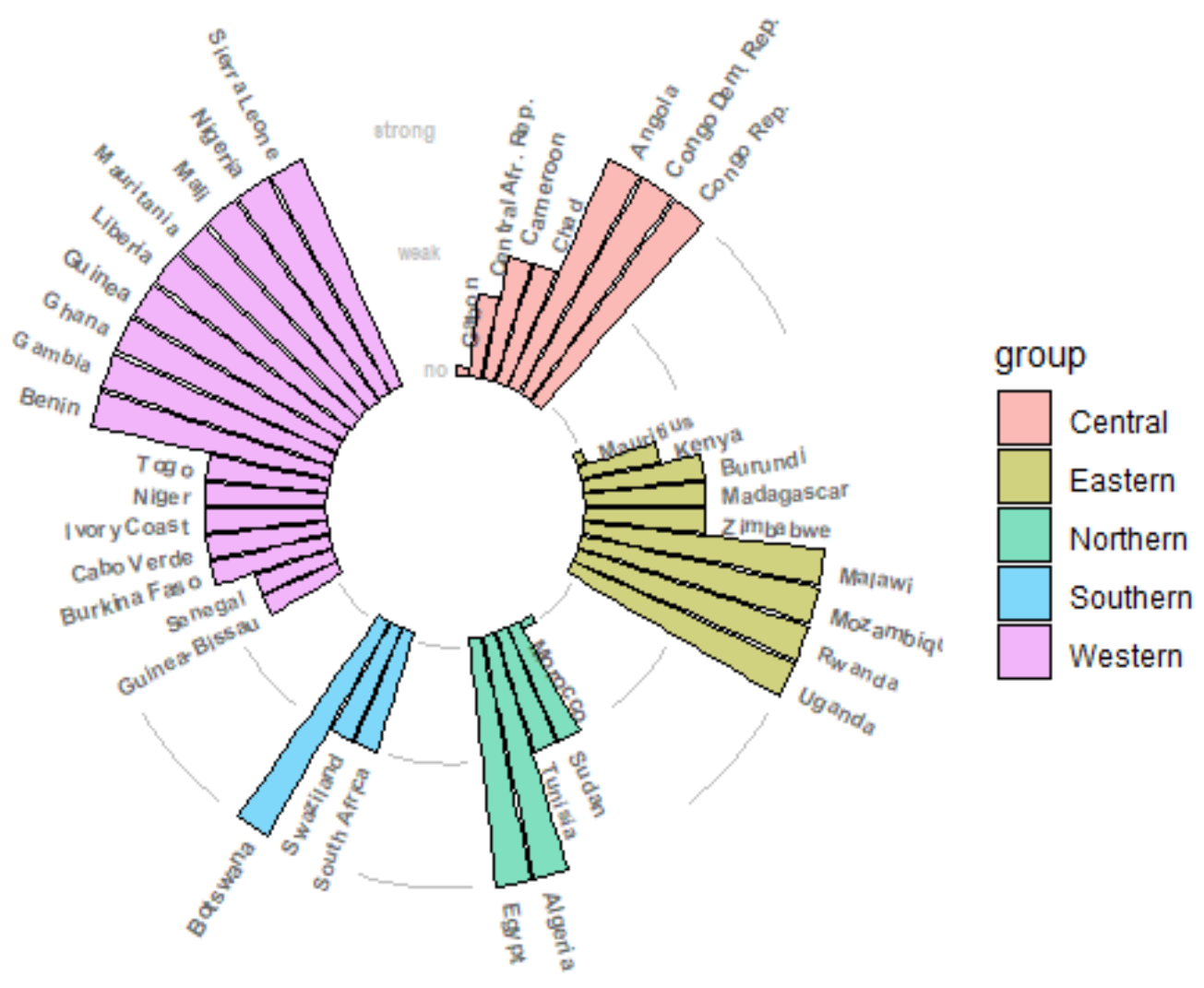

Since Dickey and Fuller (1981) test reveals that exports and imports plus IPED are integrated variables of order one in country analysis. We can therefore test their cointegration relationship. And for this purpose, we rely on the cointegration tests proposed by, Bayer and Hanck (2013)

\footnotetext{
${ }^{4}$ For space requirement, results were not report here but are available on request.
} 
for linear approach and Enders and Siklos (2001) for nonlinear approach. Table 6 and Table 7 respectively report results of linear and threshold cointegration. From the linear approach, the Bayer and Hanck (2013) cointegration test reveals that current account is sustainable in only thirteen (13) African economies.

[INSERT TABLE 6 AROUND HERE]

As pointed out by Donoso and Martin (2014), misclassifying a stable nonlinear process as nonstationary can be misleading. Traditional unit root and cointegration tests may lead to erroneously accepting no sustainability as they suffer from a loss of power. Furthermore, a nonlinear model may outperform the linear models in terms of forecast performance as noted by Christopoulos and León-Ledesma (2010). Table 7 reports results from nonlinear cointegration test between imports and exports for African economies, using TAR model ${ }^{5}$. The optimal threshold value $\tau$ minimizing the residuals sums of squares was estimated using Chan (1993) method. The estimated threshold value for each country are also reported in Table 7.

[INSERT TABLE 7 AROUND HERE]

A first look shows that nonlinear results are in agreement with panel group analysis. Indeed, with nonlinear approach current account is sustainable in thirty seven (37) African economies. Current account is not sustainable only for Gabon, Mauritius and Morocco. The approach used here is better than the linear approach.

\footnotetext{
${ }^{5}$ We also apply nonlinear cointegration test between exports and imports plus IPED using M-TAR model. Results are close to TAR model. For space requirement, they were not report here but are available on request.
} 
Figure 3. Non-linear cointegration in African economies by Income

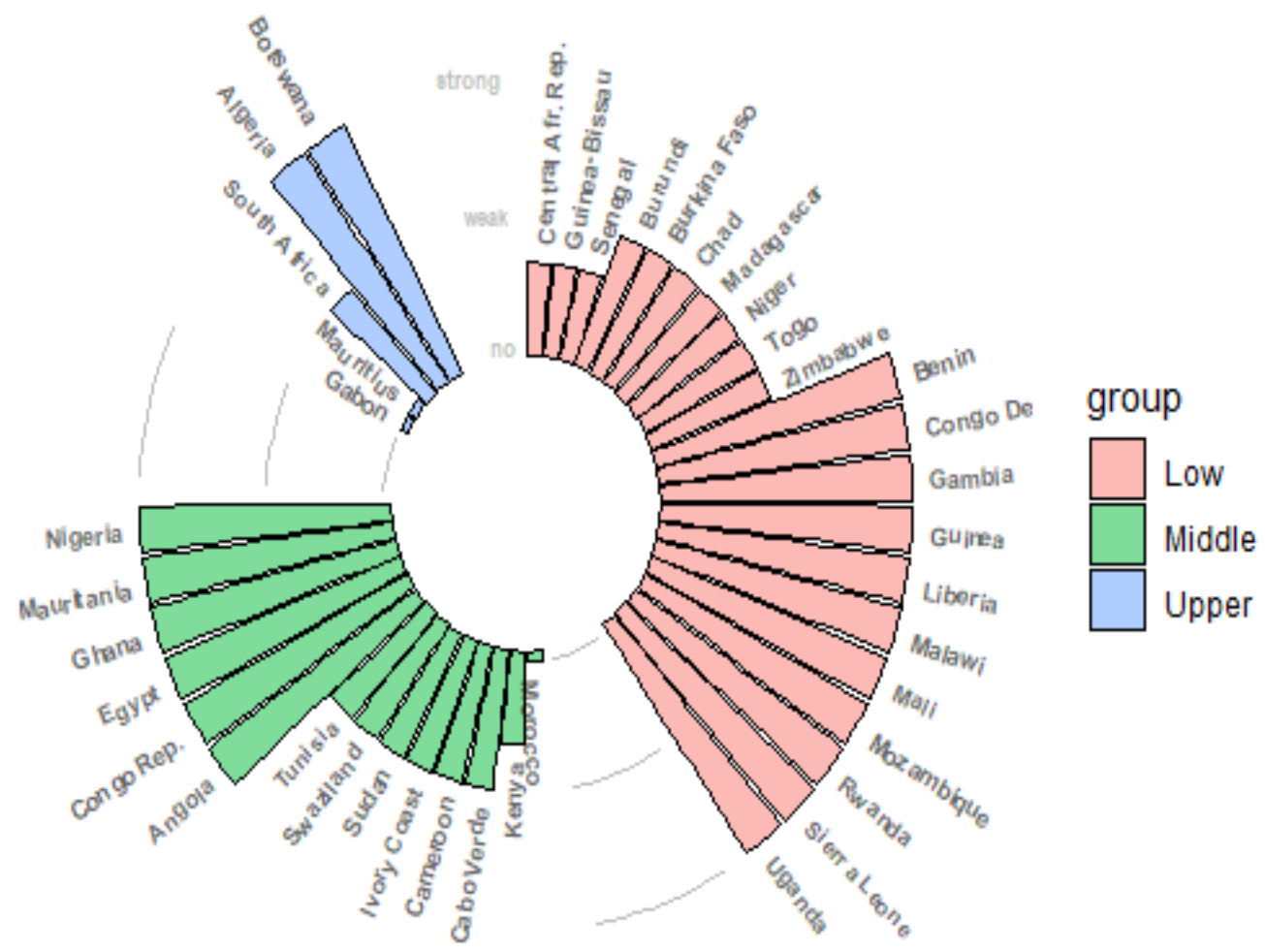


Figure 4. Non-linear cointegration in African economies by Regime

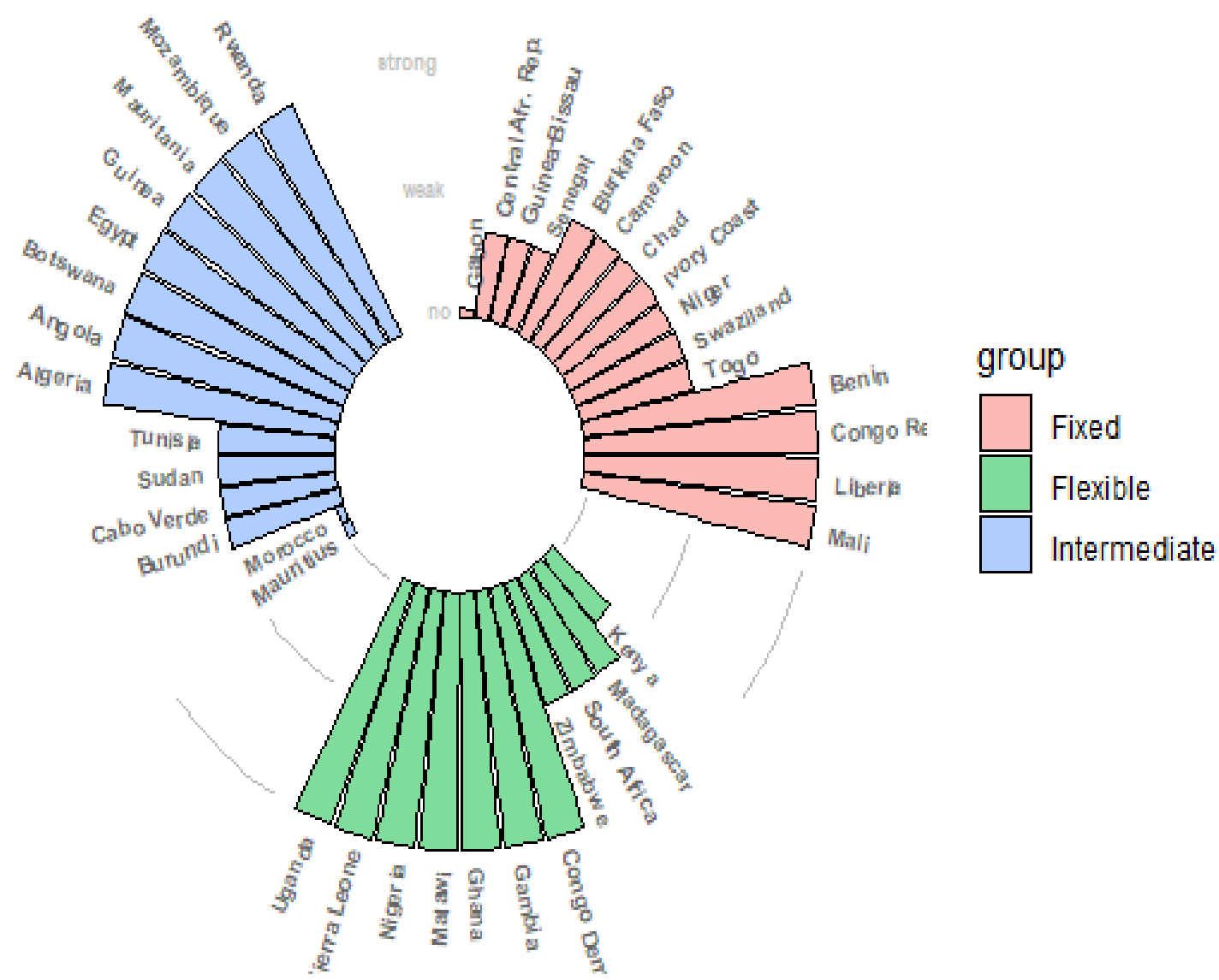

\subsection{A Further Assessment}

Table 8 reports results of PDOLS estimate ${ }^{6}$ in African economies considering Regional blocs, Income level and Exchange regime rate. As we see, the null hypothesis - of no significant sustainability coefficient - is strongly rejected in all cases and whatever the grouping is. This confirms that the current account has been globally sustainable in Africa ${ }^{7}$. When we consider regional blocs, the level of current account sustainability is highest in

\footnotetext{
${ }^{6}$ Note that these estimations are done with R codes using package pdolsms of Khraishi (2016).

7 These results are similar to those of Holmes et al. (2003), Chu et al. (2007), Gnimassoun and Coulibaly (2014), Amba et al. (2017), and Do and Amba (2018).
} 
Northern and Eastern Africa. For all the five regions, Southern Africa has the lowest coefficient of sustainability. One interesting point to observe is that when we progressively incorporate common time effects and heterogeneous linear trend, the sustainability coefficient decreases and becomes less than one. One reason for such decrease in the parameter is that including period effects might reduce the amount of cross-section dependence present in the data. We also test whether this sustainability coefficient is significantly different from one to assess whether the degree of external sustainability in Africa has been weak or strong using our empirical efficiency criteria. And we found that the sustainability of current accounts are strong in all African regions. When we regroup the same African countries by income level, in model 4, the level of current account sustainability is higher and close to one in middle-economies (0.982), followed by low-economies (0.904) and finally high-income economies (0.748). And the sustainability of current account is found to be weak only in upper-economy group. When we focus on exchange rate regime (in model 4), our findings show that the level of current account sustainability is higher in countries operating intermediate exchange rate regimes (1.017) than in countries having flexible (0.906) or fixed regimes (0.836). For all regimes and data considered, the coefficient of sustainability is not significantly different from unity. Even if the use of panel data has a number of merits over time-series data, however Dumitrescu and Hurlin (2012) pointed out that a caution is needed when interpreting panel data results. As in Amba et al. (2017), the next paragraph tries to overlap this weakness by a time-series country analysis.

[INSERT TABLE 8 AROUND HERE]

For an intensive analysis between African economies, we plot results of Table 7 and Table 8 in Figure 2, Figure 3 and Figure 4.. Focusing on regional blocs, Figure 2, the efficiency criteria 
gives a strong sustainability rate of $43 \%$ in Central Africa, $44 \%$ in Eastern Africa, $40 \%$ in Northern Africa, 33\% in Southern Africa and 56\% in Western Africa. According to income level, Figure 3 shows a rate of 52\% in Low income economies, $43 \%$ in Middle income economies and 50\% in Upper income economies. According to exchange rate regimes, Figure 4 shows a strong sustainability rate of $27 \%$ for Fixed exchange rate economies, $64 \%$ for Flexible exchange rate economies and $57 \%$ for Intermediate exchange rate economies. Among these three groupings, it seems that only exchange rate regimes has a significant effect on the current account sustainability. Indeed, current account is strongly sustainable in countries operating flexible and intermediate exchange rate regimes than countries operating fixed regimes. Our findings are the same as as Gnimassoun and Coulibaly (2014) and Do and Amba (2018).

\section{Conclusion and Recommendations}

The aim of this paper was to investigate the current account sustainability in African countries by testing the existence of a linear and nonlinear cointegration relationship between exports and imports plus interest payments on external debt countries over the $1980-2016$ period. The paper also tests if this sustainability depends on: regional blocs, income level and exchange rate regimes. The conceptual framework to the analysis is provided by a model of current account sustainability developed by Hakkio and Rush (1991), and Husted (1992). To this end, our analysis focused on a dual cointegration approach in order to achieve the goal of this study: a panel group analysis based on Westerlund (2007) panel cointegration and PDOLS estimates and a country analysis which used linear (Bayer and Hanck, 2013) and nonlinear (Enders and Siklos, 2001) cointegration approaches.

Using a sample of forty (40) African economies over the period 1980 to 2016 our findings show that: the current account has been globally sustainable in African groups; the individual 
cointegration tests findings suggest that the current accounts for $8 \%$ African countries are unsustainable, but the Wald restriction test on the cointegrating coefficient reveals that the current account deficits are weakly sustainable for $45 \%$ African economies. Therefore, these countries should implement policies to reinforce the sustainability of the current account deficits. Most especially, for economies with unsustainable current account, they should put in place policies to reduce its current account deficit in order to recover its external stability. Countries should implement policies that improve current account balances. These include policies that can accelerate real GDP growth rates, improve trade openness and capital openness (Das, 2016). Among regional blocs, income level and exchange regime rate groupings, it seems that only exchange rate regimes has a significant effect on current account sustainability. Since current account is strong sustainable in countries operating flexible and intermediate exchange rate regimes than countries operating fixed regimes. Therefore, it is recommended that African economies adapt either flexible or intermediate exchange rate regimes.

\section{Declarations}

Availability of Data: This data used in this study is from the OECD Quarterly International Trade Statistics 1980 to 2016. This data has third party restrictions, but will be produced on request.

Competing Interest: This is to declare that none of the co-authors has any competing interest for the submission and publication of this journal. This article has not submitted to any other journal for publication consideration.

Funding: There were no external funds used to do this research. Authors used their personal funds to acquire data and analytical software. All financial contributions were done by the coauthors. 
Authors' Contributions: The authors made equal contributions to the data collection and analysis, write-up, referencing. This implies $33.3 \%$ contribution by each author.

Acknowledgements: The authors are grateful to National Institute of Statistics for availing the required data. Similarly, the authors are also grateful to Chan (2011), Gnimassoun and Coulibaly, (2014) and Hashinguchi and Hanori, (2012) for granting them permission to apply their analytical framework in this current study. All grammatical and calculation errors remain to be the responsibility of the authors.

\section{References}

Aizenman, J. and Sun, Y. (2010). 'Globalization and the sustainability of large current account imbalances: Size matters', Journal of Macroeconomics, 32(1), 35-44. Apergis, N., Katrakilidis, K. P., and Tabakis, N. M. (2000). 'Current account deficit sustainability: the case of greece', Applied Economics Letters, 7(9), 599-603.

Baharumshah, A. Z., Lau, E., and Fountas, S. (2005) 'Current account deficit sustainability: A panel approach', Journal of Economic Integration, 20(3), 514-529.

Banerjee, A., Dolado, J., and Mestre, R. (1998). 'Error-correction mechanism tests for Cointegration in a single-equation framework', Journal of Time Series Analysis, 19(3), 267-283.

Bayer, C. and Hanck, C. (2013). 'Combining non-cointegration tests', Journal of Time Series Analysis, 34(1), 83-95.

Boswijk, H. P. (1994). 'Testing for an unstable root in conditional and structural error 
Correction models', Journal of Econometrics, 63(1), 37-60.

Chan, K.-S. (1993). 'Consistency and limiting distribution of the least squares estimator of a threshold autoregressive model', The Annals of Statistics, 21(1), 520-533.

Chang, C.-K., Chang, T., et al. (2012). 'Revisiting the sustainability of current account deficit: Spsm using the panel KSS test with a Fourier function', Economics Bulletin, 32(1), $538-550$.

Chen, S.-W. (2011). 'Current account deficits and sustainability: Evidence from the OECD Countries', Economic Modelling, 28(4), 1455-1464.

Chinn, M. D. and Prasad, E. S. (2003). 'Medium-term determinants of current accounts in Industrial and developing countries: an empirical exploration', Journal of International Economics, 59(1), 47-76.

Christopoulos, D. and León-Ledesma, M. A. (2010). 'Current account sustainability in the US: What did we really know about it?', Journal of International Money and Finance, 29(3), 442-459.

Chu, H.-P., Chang, T., Chang, H.-L., Su, C.-W., and Yuan, Y. (2007). 'Mean reversion in the current account of forty-eight African countries: Evidence from the panel SURADF test', Physica A: Statistical Mechanics and its Applications, 384(2), 485-492.

Clarida, R. H. (2006). 'G7 current account imbalances: Sustainability and adjustment', Technical report, National Bureau of Economic Research.

Coudert, V. and Couharde, C. (2007). 'Real equilibrium exchange rate in china is the 
Renminbi undervalued?', Journal of Asian Economics, 18(4), 568-594.

Das, D.K. (2016). Determinants of Current Account Imbalances in the Global Economy: A Dynamic Panel Analysis. Economic Structure 8(2016)

Dickey, D. A. and Fuller, W. A. (1981). 'Likelihood ratio statistics for autoregressive time Series with a unit root', Econometrica, 49(4), 1057-1072.

Donoso, V. and Martin, V. (2014). 'Current account sustainability in Latin America', The Journal of International Trade \& Economic Development, 23(5), 735-753.

Dumitrescu, E.-I. and Hurlin, C. (2012). 'Testing for Granger non-causality in heterogeneous Panels', Economic Modelling, 29(4), 1450-1460.

Edwards, S. (2005). 'Is the US current account deficit sustainable? and if not, how costly is adjustment likely to be?', Technical report, National Bureau of Economic Research.

Enders, W. and Granger, C. W. J. (1998). 'Unit-root tests and asymmetric adjustment with an example using the term structure of interest rates', Journal of Business \& Economic Statistics, 16(3), 304-311.

Enders, W. and Siklos, P. L. (2001). 'Cointegration and threshold adjustment', Journal of Business \& Economic Statistics, 19(2), 166-176.

Engle, R. F. and Granger, C.W.J (1987). 'Co-integration and error correction: representation, estimation, and testing', Econometrica, 55(2), 251-276.

Faruqee, H. and Debelle, G. (1998). 'Vi saving-investment balances in industrial countries: An empirical investigation', Exchange Rate Assessment: Extension of the 
Macroeconomic Balance Approach, 167.

Gnimassoun, B. and Coulibaly, I. (2014). Current account sustainability in Sub-Saharan

Africa: Does the exchange rate regime matter?', Economic Modelling, 40@, 208-226.

Gnimassoun, B., Mignon, V., et al. (2013). 'Current-account adjustments and exchange-rate

Misalignments', Technical report, CEPII Working Paper.

Hakkio, C. S. and Rush, M. (1991). 'Is the budget deficit 'too large?' '. Economic Inquiry, 29(3), 429-445.

Hashiguchi, Y. and Hamori, S. (2012). 'The sustainability of trade balances in Sub-Saharan

Africa: panel cointegration tests with cross-section dependence', Applied Economics Letters, 19(2), 161-165.

Herzer, D., Nowak-Lehmann, D., et al. (2005). 'Are exports and imports of Chile cointegrated?', Technical report, Discussion papers//Ibero America Institute for Economic Research.

Holmes, M. J. et al. (2003). 'Are the trade deficits of less developed countries stationary?. Evidence for African countries', Applied Econometrics and International Development, 3(3), 7-24.

Husted, S. (1992). 'The emerging us current account deficit in the 1980s: a cointegration Analysis', The Review of Economics and Statistics, 74(1), 159-166.

Ilzetzki, E., Reinhart, C., and Rogoff, K. (2008). 'The country chronologies and background Material to exchange rate arrangements in the 21 st century: Which anchor will hold? 
Unpublished.

IMF, I. (2017). Regional Economic Outlook: Sub-Saharan Africa Fiscal Adjustment and Economic Diversification. Washington, DC.

Jeong, S.-E. and Mazier, J. (2003). 'Exchange rate regimes and equilibrium exchange rates in East Asia', Revue Economique, 54(5), 1161-1182.

Johansen, S. (1988). 'Statistical analysis of cointegration vectors', Journal of Economic Dynamics and Control, 12(2-3), 231-254.

Kao, C. and Chiang, M.-H. (2001). 'On the estimation and inference of a cointegrated Regression in panel data', In Badi H. Baltagi, Thomas B. Fomby, R. C. H. E., Editor, Nonstationary Panels, Panel Cointegration, and Dynamic Panels, pages 179-222. Emerald Group Publishing Limited.

Karunaratne, N. D. (2010). 'The sustainability of Australia's current account deficits—a Reappraisal after the global financial crisis', Journal of Policy Modeling, 32(1), 8197.

Khraishi, R. (2016). PDOLMS: Panel Dynamic OLS Estimation of Cointegrating Vectors. R Package version 0.2.

Kim, B.-H., Min, H.-G., Hwang, Y.-S., and McDonald, J. A. (2009). 'Are Asian countries' Current accounts sustainable? deficits, even when associated with high investment, are not costless', Journal of Policy Modeling, 31(2), 163-179.

Kincaid, G. R., Fetherston, M., Isard, P., Faruqee, H., et al. (2001). 'Methodology for current 
account and exchange rate assessments', Technical report, International Monetary Fund.

Lane, P. R. and Milesi-Ferretti, G. M. (2012). 'External adjustment and the global crisis', Journal of International Economics, 88(2), 252-265.

Lanzafame, M. (2014). 'Current account sustainability in advanced economies', The Journal of International Trade \& Economic Development, 23(7), 1000-1017.

Lee, M. J., Ostry, M. J. D., Prati, M. A., Ricci, M. L. A., and Milesi-Ferretti, M. G.-M. (2008). Exchange rate assessments: CGER methodologies. Number 261. International Monetary Fund.

Maddala, G. S. and Wu, S. (1999). 'A comparative study of unit root tests with panel data and A new simple test', Oxford Bulletin of Economics and Statistics, 61(S1), 631-652. Mark, N. C. and Sul, D. (2003). 'Cointegration vector estimation by panel DOLS and longrun money demand', Oxford Bulletin of Economics and Statistics, 65(5), 655-680. Milesi-Ferrett, G. M. and Razin, A. (1996). 'Sustainability of persistent current account deficits', Technical report, National Bureau of Economic Research.

Mundell, R. A. (1961). 'A theory of optimum currency areas', The American Economic Review, 51(4), 657-665.

Narayan, K.P. and Narayan, S. (2005). 'Are exports and imports cointegrated? Evidence from 22 least developed countries', Applied Economics Letters, 12(6), 375 -378 .

Ndoricimpa, A., Achandi, E. L., et al. (2014). 'Are current account deficits sustainable in 
EAC countries? evidence from threshold cointegration', Economics Bulletin,

34(3), 1990-2001.

Ongan, S. (2008). 'The sustainability of current account deficits and tourism receipts in

Turkey', The International Trade Journal, 22(1), 39-62.

Pancaro, C. and Saborowski, C. (2016). 'Current account reversals in industrial countries:

does the exchange rate regime matter?', International Journal of Finance \& Economics, 21(2), 107-130.

Pesaran, M. H. (2007). 'A simple panel unit root test in the presence of cross-section

Dependence', Journal of Applied Econometrics, 22(2), 265-312.

Rahman, M. Z. (2011). 'Existence of export-import cointegration: A study on Indonesia and Malaysia', International Business Research, 4(3):108.

Reese, S. and Westerlund, J. (2016). 'PANICCA: Panic on cross-section averages', Journal of Applied Econometrics, 31(6), 961-981.

Rinaldi, A., Pistoresi, B., et al. (2014). ‘A note on Italy’s current account sustainability: 1861 -2010’, Economics Bulletin, 34(2), 1197-1204.

Roubini, N. and Wachtel, P. (1999). 'Current-account sustainability in transition economies', In Skreb, M. and Blejer, M., editors, Balance of Payments, Exchange Rates, and Competitiveness in Transition Economies, Chapter 2, pages 19-93. Kluwer Academic ublishers.

Sahoo, M., Babu, M. S., and Dash, U. (2016). 'Long run sustainability of current account balance of China and India: New evidence from combined cointegration test', 
Intellectual Economics, 10(2), 78-91.

Stigler, M. (2012). 'Threshold cointegration: overview and implementation in R (revision 4).

Sun, C. (2011). 'Price dynamics in the import wooden bed market of the United States', Forest Policy and Economics, 13(6), 479-487.

Tiwari, A. K. (2015). 'Reassesment of sustainability of current account deficit in India', South Eastern Europe Journal of Economics, 10(1), 67-79.

Ventosa-Santaulauria, D., Gomez-Zaldivar, M., Perez, L. A., et al. (2013). 'Long-run Relationship with shifts between Mexican current account revenues and expenditures', Economics Bulletin, 33(2),1317-1327.

Westerlund, J. (2007). 'Testing for error correction in panel data', Oxford Bulletin of Economics and Statistics, 69(6), 709-748.

World Bank (2018). World development indicators. Washington, DC: The World Bank. Zivot, E. and Andrews, D. W. K. (2002). 'Further evidence on the great crash, the oil-price shock, and the unit-root hypothesis', Journal of Business \& Economic Statistics, $20(1), 25-44$. 
Figures

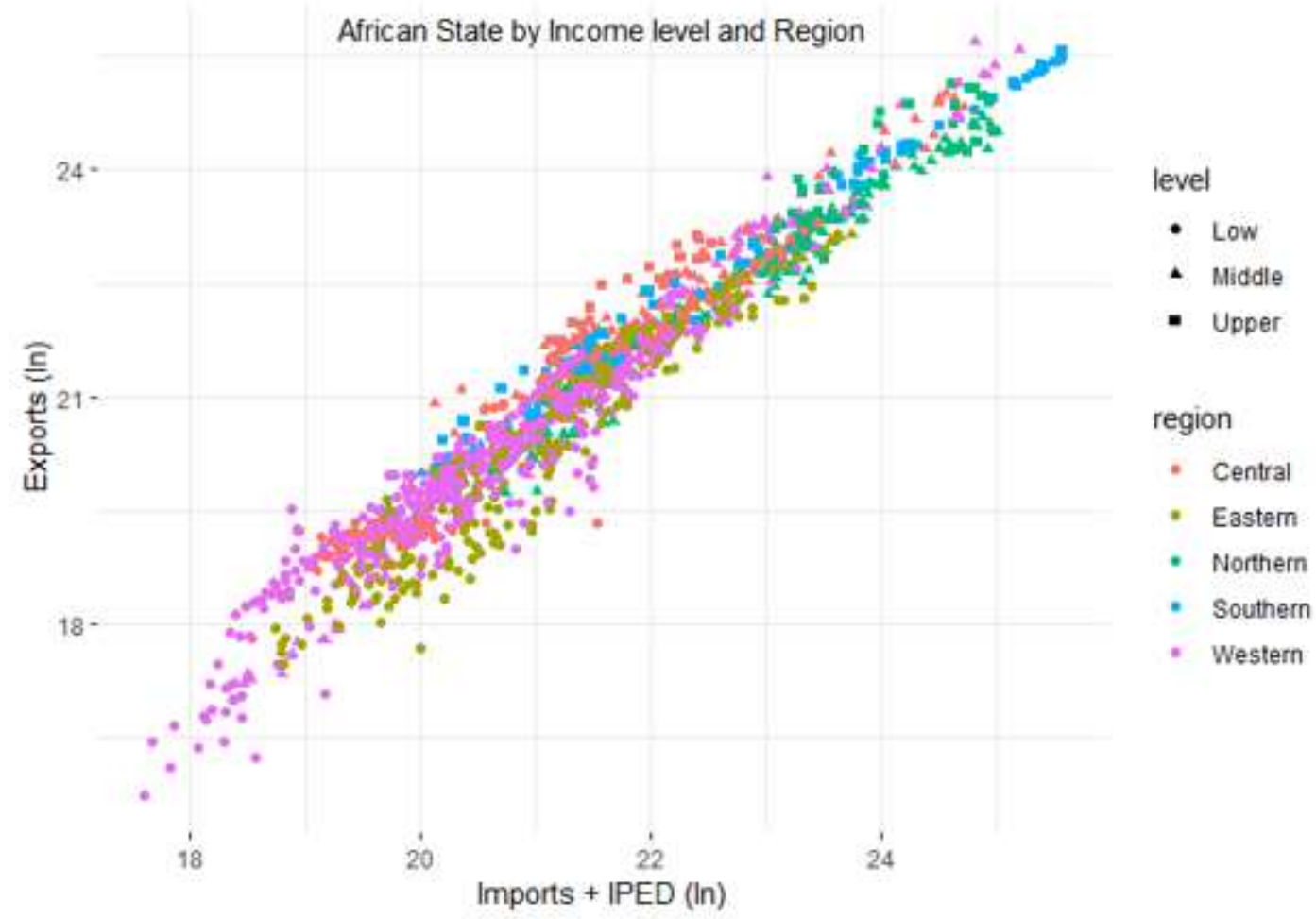

Figure 1

Export and Import plus interest payments on external debts in Africa 


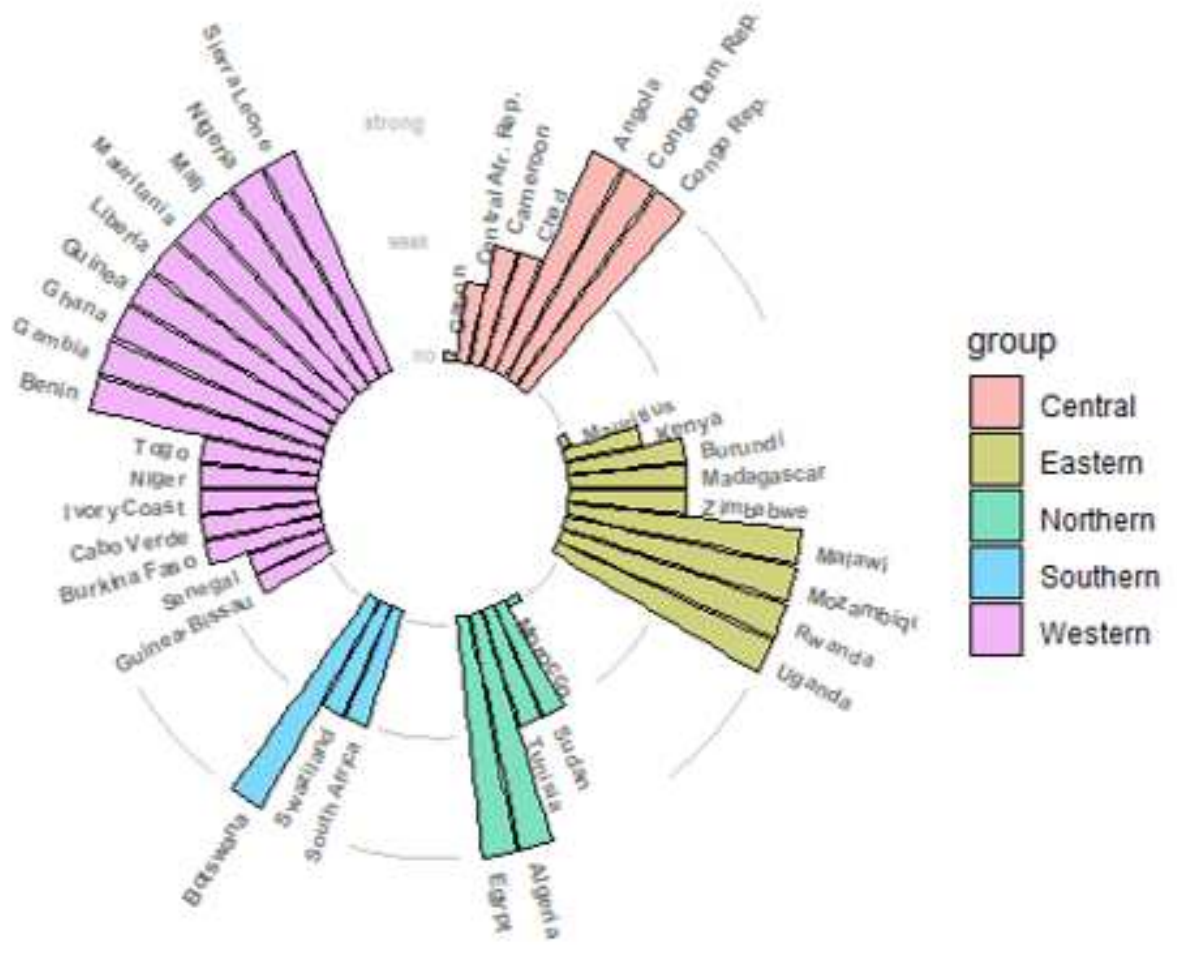

Figure 2

Non-linear cointegration in African economies by region

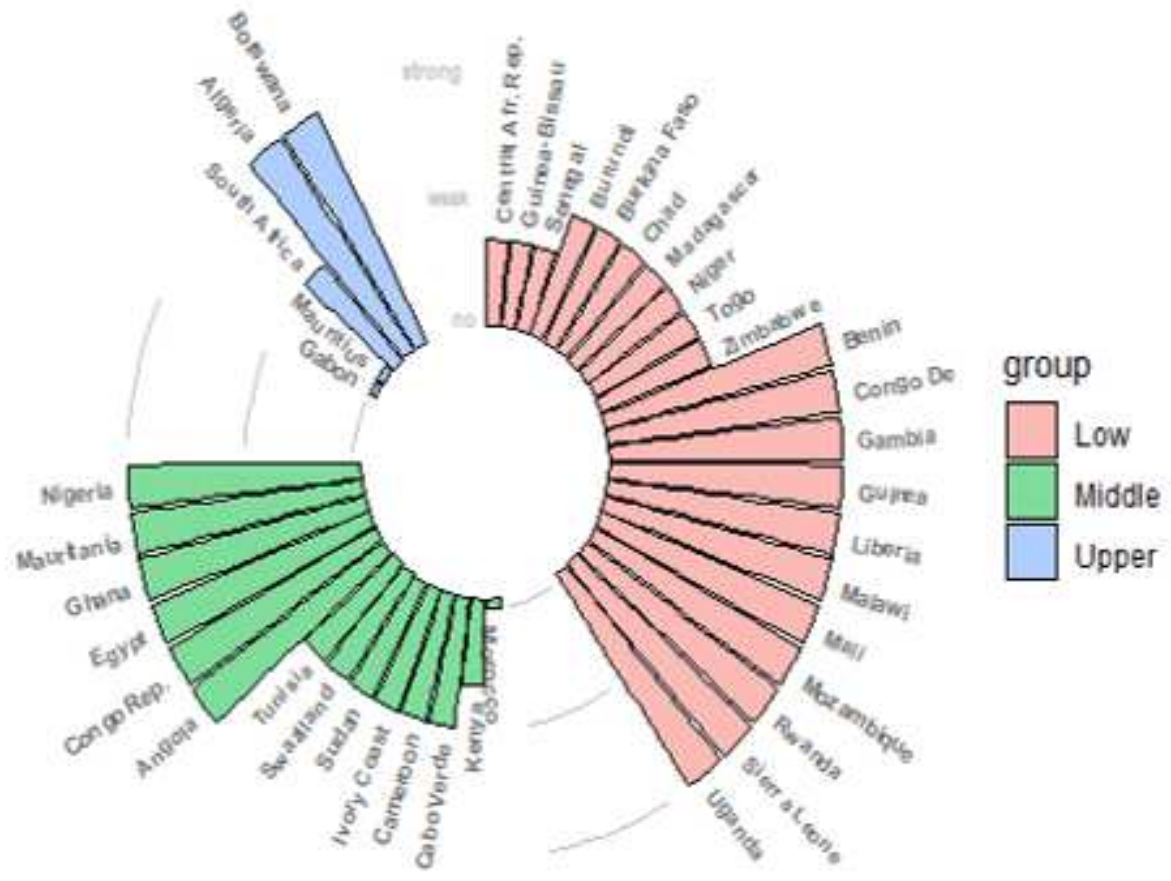


Figure 3

. Non-linear cointegration in African economies by Income

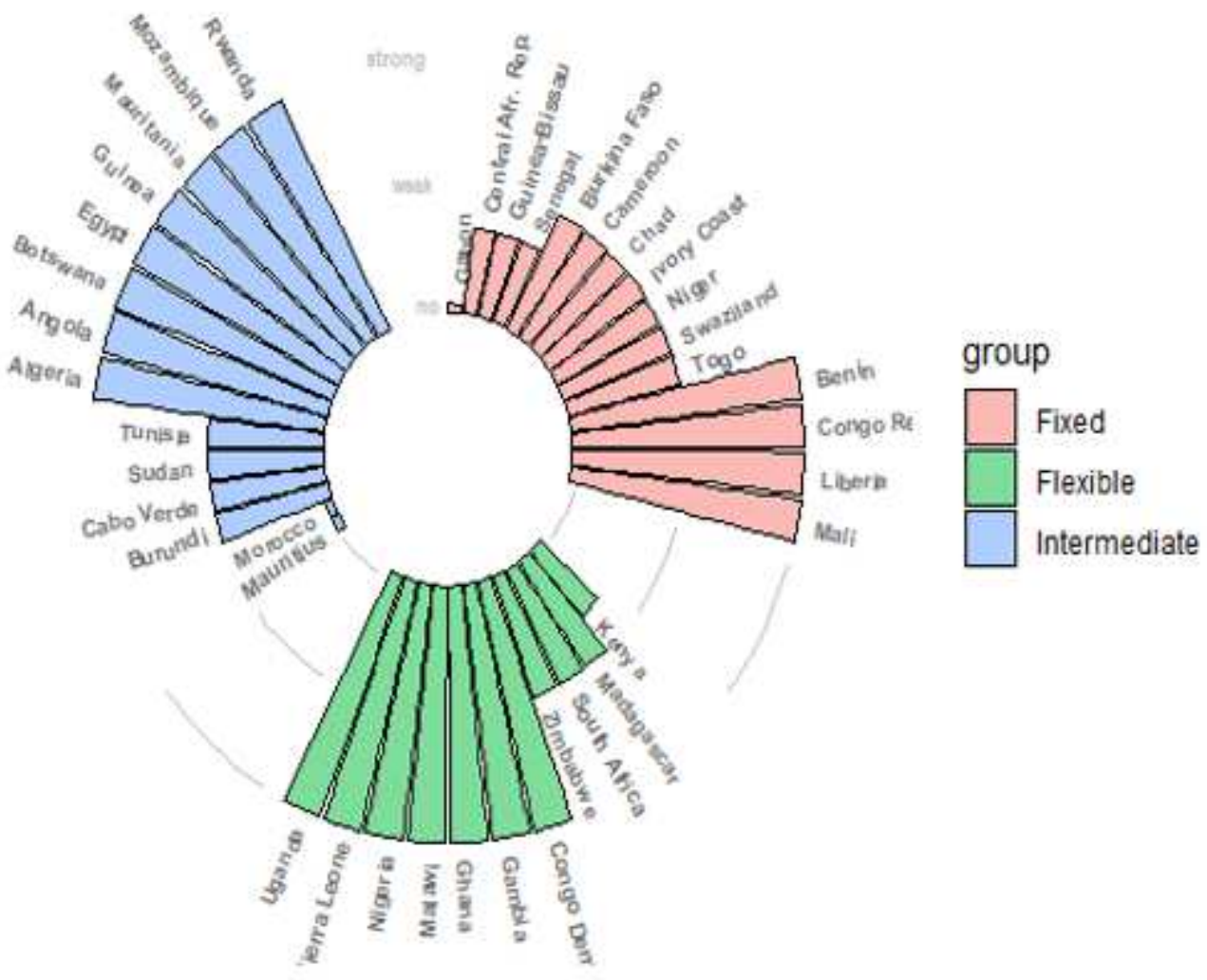

\section{Figure 4}

Non-linear cointegration in African economies by Regime 